OPEN ACCESS

Edited by:

George S. Bullerjahn,

Bowling Green State University,

United States

Reviewed by:

Vidya De Gannes,

The University of the West Indies at St. Augustine, Trinidad and Tobago

Daniel von Schiller,

University of the Basque Country (UPV/EHU), Spain

*Correspondence:

Yu Zhen

zhenyu@ouc.edu.cn

Specialty section: This article was submitted to Aquatic Microbiology,

a section of the journal

Frontiers in Microbiology

Received: 25 July 2017 Accepted: 18 January 2018

Published: 02 February 2018

Citation:

He $H$, Zhen Y, Mi T, Fu L and Yu Z (2018) Ammonia-Oxidizing Archaea and Bacteria Differentially Contribute to Ammonia Oxidation in Sediments from Adjacent Waters of Rushan Bay,

China. Front. Microbiol. 9:116

doi: 10.3389/fmicb.2018.00116

\section{Ammonia-Oxidizing Archaea and Bacteria Differentially Contribute to Ammonia Oxidation in Sediments from Adjacent Waters of Rushan Bay, China}

\author{
Hui He ${ }^{1,2,3}$, Yu Zhen ${ }^{2,3,4 *}$, Tiezhu Mi ${ }^{2,3,4}$, Lulu Fu ${ }^{1,2,3}$ and Zhigang Yu ${ }^{2,5}$ \\ ${ }^{1}$ College of Marine Life Science, Ocean University of China, Qingdao, China, ${ }^{2}$ Laboratory for Marine Ecology and \\ Environmental Science, Qingdao National Laboratory for Marine Science and Technology, Qingdao, China, ${ }^{3}$ Key Laboratory \\ of Marine Environment and Ecology, Ministry of Education, Qingdao, China, ${ }^{4}$ College of Environmental Science and \\ Engineering, Ocean University of China, Qingdao, China, ${ }^{5}$ Key Laboratory of Marine Chemistry Theory and Technology, \\ Ministry of Education, Qingdao, China
}

Ammonia oxidation plays a significant role in the nitrogen cycle in marine sediments. Ammonia-oxidizing archaea $(\mathrm{AOA})$ and bacteria $(\mathrm{AOB})$ are the key contributors to ammonia oxidation, and their relative contribution to this process is one of the most important issues related to the nitrogen cycle in the ocean. In this study, the differential contributions of $\mathrm{AOA}$ and $\mathrm{AOB}$ to ammonia oxidation in surface sediments from adjacent waters of Rushan Bay were studied based on the ammonia monooxygenase $(a m o A)$ gene. Molecular biology techniques were used to analyze ammonia oxidizers' community characteristics, and potential nitrification incubation was applied to understand the ammonia oxidizers' community activity. The objective was to determine the community structure and activity of $A O A$ and $A O B$ in surface sediments from adjacent waters of Rushan Bay and to discuss the different contributions of $\mathrm{AOA}$ and $\mathrm{AOB}$ to ammonia oxidation during summer and winter seasons in the studied area. Pyrosequencing analysis revealed that the diversity of AOA was higher than that of $\mathrm{AOB}$. The majority of $\mathrm{AOA}$ and $\mathrm{AOB}$ clustered into Nitrosopumilus and Nitrosospira, respectively, indicating that the Nitrosopumilus group and Nitrosospira groups may be more adaptable in studied sediments. The AOA community was closely correlated to temperature, salinity and ammonium concentration, whereas the AOB community showed a stronger correlation with temperature, chlorophyll-a content (chla) and nitrite concentration. GPCR results showed that both the abundance and the transcript abundance of $\mathrm{AOA}$ was consistently greater than that of $\mathrm{AOB}$. $\mathrm{AOA}$ and $\mathrm{AOB}$ differentially contributed to ammonia oxidation in different seasons. AOB occupied the dominant position in mediating ammonia oxidation during summer, while AOA might play a dominant role in ammonia oxidation during winter.

Keywords: pyrosequencing, ammonia-oxidizing archaea, ammonia-oxidizing bacteria, potential nitrification rates, sediment, Rushan Bay 


\section{INTRODUCTION}

Nitrification is one of the most essential steps in the nitrogen cycle, including the microbial oxidation of ammonia to nitrite and subsequently to nitrate. As the rate-limiting step in nitrification, ammonia oxidation is catalyzed by a series of phylogenetic and physiological microorganisms (Winogradsky, 1890; Venter et al., 2004; Könneke et al., 2005; Treusch et al., 2005). Before ammonia-oxidizing archaea (AOA) were found in Crenarchaeota in 2004, ammonia-oxidizing bacteria (AOB) were always considered the only contributors to ammonia oxidation. As a membrane-bound enzyme, ammonia monooxygenase (AMO) is an important functional protein for ammonia oxidation and can oxide ammonium in AOA and AOB (Rotthauwe et al., 1997; Könneke et al., 2005). By encoding the active site of ammonia monooxygenase, amoA can oxide ammonia and generate energy for the sequential oxidation reaction (Hooper et al., 1997; Junier et al., 2010). Thus, the amoA gene has been widely applied in molecular ecology research of AOA and AOB in different environments, such as lakes (Jiang et al., 2009; Hou et al., 2013b), wetlands (Ye et al., 2011; Sims et al., 2012a,b), soils (He et al., 2007; de Gannes et al., 2012; Wang et al., 2014; Zhao et al., 2015) and estuaries (Caffrey et al., 2007; Jin et al., 2011; Zheng et al., 2013). Compared with AOB, AOA predominates in many environments, indicating that the ammonia oxidation process promoted by AOA may be more intense (Shen et al., 2008; Jin et al., 2011; Hou et al., 2013a). The relative contribution of $\mathrm{AOA}$ and $\mathrm{AOB}$ to ammonia oxidation is one of the most important issues related to the nitrogen cycle in the ocean.

Studies have shown that salinity (Caffrey et al., 2007; Mosier and Francis, 2008; Santoro et al., 2008), ammonium concentration (Di et al., 2009; Niu et al., 2013; de Gannes et al., 2014) and dissolved oxygen concentration (Park et al., 2006; Santoro et al., 2008; Liu et al., 2011) are potential factors influencing the community structure of AOA and AOB. As electron acceptor and donor, oxygen and ammonia are essential for ammonia oxidation, but for $\mathrm{AOA}$ and $\mathrm{AOB}$, the affinities of ammonia and oxygen differ. It has been found that AOA prefer areas with low ammonium concentrations while AOB prefer areas with high ammonium concentrations (Di et al., 2009), and several researchers have found that AOA show better survival than AOB under conditions of low dissolved oxygen (Kayee et al., 2011; Limpiyakorn et al., 2013). In addition to these factors, ammonia oxidizers' communities were also affected by distinct seasonal variations. A previous study in Catalina Harbor showed that the $\mathrm{AOA}$ and $\mathrm{AOB}$ amoA gene copy numbers were greater in summer than in winter (Beman et al., 2012). In a seasonal study of AOA in the deep oligotrophic Lake Lucerne, the amoA gene copy numbers matched the seasonal dynamics within 16 months (Vissers et al., 2013). Seasonal changes in the amoA gene also reflected the dynamic changes in AOA community characteristics in oligotrophic high mountain lakes (Auguet et al., 2011).

Potential nitrification rates (PNR) are measured by the addition of excess ammonium under optimal conditions, and they can be applied to compare the different contributions of $\mathrm{AOA}$ and $\mathrm{AOB}$ to ammonia oxidation. Several studies have shown a correlation between PNR and amoA gene copy numbers. For example, PNR was positively related to the abundance of archaeal amo $A$ gene, but it showed no significant correlation with bacterial amoA gene abundance in several southeastern regions of America (Caffrey et al., 2007). Wankel et al. (2011) were the first group to relate the amo $A$ gene abundance to ${ }^{15} \mathrm{~N}$ isotope methods and found no obvious correlations between them in the Elkhorn Slough estuary. A positive correlation was also found between PNR and the archaeal amoA gene abundance in Yangtze estuarine sediments, suggesting that AOA might be more important for mediating ammonia oxidation in this area (Zheng et al., 2014).

Rushan Bay is a typical semi-enclosed sea and an important mariculture area in Shandong Peninsula, China. With the development of industry and aquaculture, large quantities of nitrogen $(\mathrm{N})$ and phosphorous $(\mathrm{P})$ nutrients have been transported into this area, contributing to a series of ecological problems such as eutrophication. Increasing nutrients and organic materials in estuarine and coastal waters can also result in an oxygen minimum zone (OMZ) or even hypoxia in the bottom water. An OMZ was previously found in Rushan Bay and its adjacent waters in 2009 (Cui et al., 2012; Ran et al., 2012). The presence of OMZ may destroy the oxidizing environment in surface sediment, which can impact the biogeochemical cycle of elements in marine environments, particularly for nitrification (Caffrey et al., 2007; Santoro et al., 2008; Qiu et al., 2013).

Sediments are habitats and can constitute enabling environments for microbes to flourish (Besaury et al., 2014). However, to date, there has been relatively little focus on the community structure and activity of AOA and AOB in surface sediments from adjacent waters of Rushan Bay. Moreover, a comprehensive understanding of the different contributions of AOA and AOB to ammonia oxidation in the studied sediments needs to be explored. In the present study, the composition, abundance and activity of AOA and AOB communities in sediments from adjacent waters of Rushan Bay were studied based on $a m o A$ gene sequences and potential nitrification incubation. Our main objectives were (1) to study the community structure and activity of $\mathrm{AOA}$ and $\mathrm{AOB}$ in surface sediments from adjacent waters of Rushan Bay, (2) to determine potential links between environmental factors and community structure, (3) to discuss the differential contributions of $\mathrm{AOA}$ and $\mathrm{AOB}$ to ammonia oxidation during summer and winter seasons in our studied area. We hypothesized that the (1) Nitrosopumilus group of AOA and Nitrosospira group of AOB would be more adaptable, exhibiting a marine influence to ammonia oxidizers' communities, (2) AOA and AOB would contribute differentially to ammonia oxidation in different seasons owing to their different nitrification potentials and transcript abundance in different seasons.

\section{MATERIALS AND METHODS}

\section{Sediment Sampling}

The surface sediments and bottom water were collected from two stations $\left(\mathrm{C} 0: 121.47^{\circ} \mathrm{E}, 36.74^{\circ} \mathrm{N} ; \mathrm{C} 2: 121.49^{\circ} \mathrm{E}, 36.66^{\circ} \mathrm{N}\right)$ from adjacent waters of Rushan Bay during July (summer) 
2014 and February (winter) 2015 (Figure 1). At each station, surface sediments (top $3 \mathrm{~cm}$ ) were obtained using the box corer. After collection, all sediment samples were thawed, mixed thoroughly, and divided into two parts: one part was immediately stored at $4^{\circ} \mathrm{C}$ until potential nitrification incubation, and the other part was transported to the laboratory at $-20^{\circ} \mathrm{C}$ and stored at $-80^{\circ} \mathrm{C}$ for molecular analysis. The bottom water were filtered through $0.45-\mu \mathrm{m}$ pore size polyethersulfone filters with $\mathrm{N}_{2}$ purging, and then immediately stored at $-20^{\circ} \mathrm{C}$ for chemical analysis. Samples were labeled as summer (S) or winter (W).

\section{Environmental Factor Analysis}

The physicochemical characteristics of the bottom water, such as salinity, temperature, chlorophyll-a content (chla) and dissolved oxygen concentration, were measured in situ with RBR XR620 Multi-Channel CTD (Elcee). The remaining environmental factors (dissolved nitrogen and phosphate concentrations) were surveyed in the laboratory with a QuAAtro nutrient auto analyzer (Seal Analytical Ltd.).

\section{Potential Nitrification Rates}

Potential nitrification rates were measured in triplicate according to the procedure of Bernhard et al. (2007) and Zheng et al. (2014). For each sample, a total of $1.0 \mathrm{~g}$ sediment was placed into 100-mL Erlenmeyer flasks with $30 \mathrm{~mL}$ seawater filtered using a $0.22-\mu \mathrm{m}$ filtration membrane. All samples were amended with $300 \mu \mathrm{M}$ ammonium (as $\mathrm{NH}_{4} \mathrm{Cl}$ ) and $60 \mu \mathrm{M}$ phosphate (as $\mathrm{KH}_{2} \mathrm{PO}_{4}$ ). The flasks were loosely covered, and then the suspension was incubated at $24^{\circ} \mathrm{C}$ (for summer) or $3.5^{\circ} \mathrm{C}$ (for winter), a temperature approximating that of the bottom water, with continuous shaking in the dark. During the incubation, subsamples were collected at 0 , 24,48 , and $72 \mathrm{~h}$ of incubation, and then centrifuged and filtered for ammonium, nitrite and nitrate analysis. $\mathrm{NH}_{4}{ }^{+}$, $\mathrm{NO}_{2}{ }^{-}$and $\mathrm{NO}_{3}{ }^{-}$concentrations were measured using a QuAAtro nutrient auto analyzer. PNRs were calculated based on the changes in nitrate and nitrite concentrations over time.

To separate the archaeal and bacterial ammonia oxidation rates, an additional $1.0 \mathrm{~g} \cdot \mathrm{L}^{-1}$ ampicillin was placed in the flasks in a parallel experiment (Zheng et al., 2014). The experiment was conducted with three replicates per sample. As a beta-lactam antibiotic, ampicillin targets bacterial cell wall production when cells grow and thus can inhibit bacteria without affecting archaea (De Souza et al., 1999).

\section{Nucleic Acid Isolation and cDNA Synthesis by Reverse Transcription}

DNA and RNA were extracted from each sediment sample using the PowerSoil ${ }^{\circledR}$ DNA Isolation Kit (MoBio) and PowerSoil ${ }^{\circledR}$ Total RNA Isolation Kit (MoBio), respectively. cDNA was synthesized with a Transcriptor First Strand cDNA Synthesis Kit (Roche). The extracted DNA and cDNA were stored at $-20^{\circ} \mathrm{C}$ for further analysis. The DNA was used for pyrosequencing and $\mathrm{qPCR}$, and the cDNA was used for qPCR.

\section{Quantitative PCR}

Each DNA and cDNA extract was used for qPCR with the following primers: CamoA-19F (5'-ATG GTC TGG YTW AGA CG) and CamoA-616R (5'-GCC ATC CAB CKR TAN GTC CA) (Pester et al., 2012) for the AOA amoA genes and amoA-1F (5'GGG GTT TCT ACT GGT GGT) and amoA-2R (5'-CCC CTC KGS AAA GCC TTC TTC) (Rotthauwe et al., 1997) for the AOB amoA genes. All qPCR assays were performed in triplicate with an ABI PRISM ${ }^{\circledR} 7500$ Sequence Detection System (Applied Biosystems) using the SYBR Green I method. The $20-\mu \mathrm{L}$ qPCR reaction system contained $10 \mu \mathrm{L}$ FastStart Universal SYBR Green Master (ROX) (Roche), $0.3 \mu \mathrm{M}$ each primer, $0.2 \mu \mathrm{g} \cdot \mu \mathrm{L}^{-1}$ bovine serum albumin (BSA) and $2.0 \mu \mathrm{L}$ sediment DNA or cDNA. The qPCR amplification was started with an initial activation at $95^{\circ} \mathrm{C}$ for $10 \mathrm{~min}$, followed by 40 cycles of $15 \mathrm{~s}$ at $95^{\circ} \mathrm{C}, 45 \mathrm{~s}$ at $54^{\circ} \mathrm{C}$ and $60 \mathrm{~s}$ at $72^{\circ} \mathrm{C}$ for $\mathrm{AOA}$, or 40 cycles of $15 \mathrm{~s}$ at $95^{\circ} \mathrm{C}$ and $2 \mathrm{~min}$ at $58^{\circ} \mathrm{C}$ for $\mathrm{AOB}$. After the amplification cycles, a melting stage was added to obtain a melting curve. Standard curves were generated using standard plasmids of AOA or AOB containing amo $A$ genes.

The abundance and the transcript abundance of the amo $A$ gene was examined using the above-mentioned qPCR protocols. In addition to the template DNA or $\mathrm{CDNA}$, each reaction included serially diluted plasmids containing the target gene and negative control to ensure that the qPCR assay was stable and uncontaminated.

\section{Pyrosequencing}

The community characteristics of $\mathrm{AOA}$ and $\mathrm{AOB}$ were studied using 454 pyrosequencing based on the amo $A$ gene. The archaeal and bacterial amoA gene fragments were amplified using the specific primer pairs CamoA-19F/CamoA-616R and amoA$1 F / a m o A-2 R$, respectively. Barcodes were ligated to the $5^{\prime}$ ends of the primers to distinguish each sample. The reactions were held at $98^{\circ} \mathrm{C}$ for $5 \mathrm{~min}$ to denature the DNA, followed by 30 cycles of $98^{\circ} \mathrm{C}$ for $30 \mathrm{~s}, 50^{\circ} \mathrm{C}$ for $45 \mathrm{~s}$ and $72^{\circ} \mathrm{C}$ for $60 \mathrm{~s}$ and a final step at $72^{\circ} \mathrm{C}$ for $7 \mathrm{~min}$. After purification with a SanPrep Column PCR Product Purification Kit (Sangon Biotechnology), pyrosequencing was conducted with the GS FLX+ Titanium platform at Personal Biotechnology in Shanghai, China.

The raw sequences obtained by pyrosequencing that exactly matched the barcodes and primers were retained. The sequences were subsequently trimmed to remove the barcodes and primers. Archaeal amoA sequences shorter than $425 \mathrm{nt}$ and bacterial amoA sequences shorted than $450 \mathrm{nt}$ were also excluded. After quality control, Uparse (Edgar, 2013) was employed to cluster the highquality sequences into operational taxonomic units (OTUs) with a 97\% similarity cutoff (Wang et al., 2015), and the most common sequence from each OTU were selected as the representative sequence.

\section{Statistical Analysis}

The richness indices (Chao 1 estimator), diversity indices (Shannon index) and Good's coverage were calculated using Quantitative Insights into Microbial Ecology (QIIME) (version 1.9.0). UPGMA clustering was conducted with the $\mathrm{R}$ program. Phylogenetic analysis was performed using MEGA6 (Tamura 


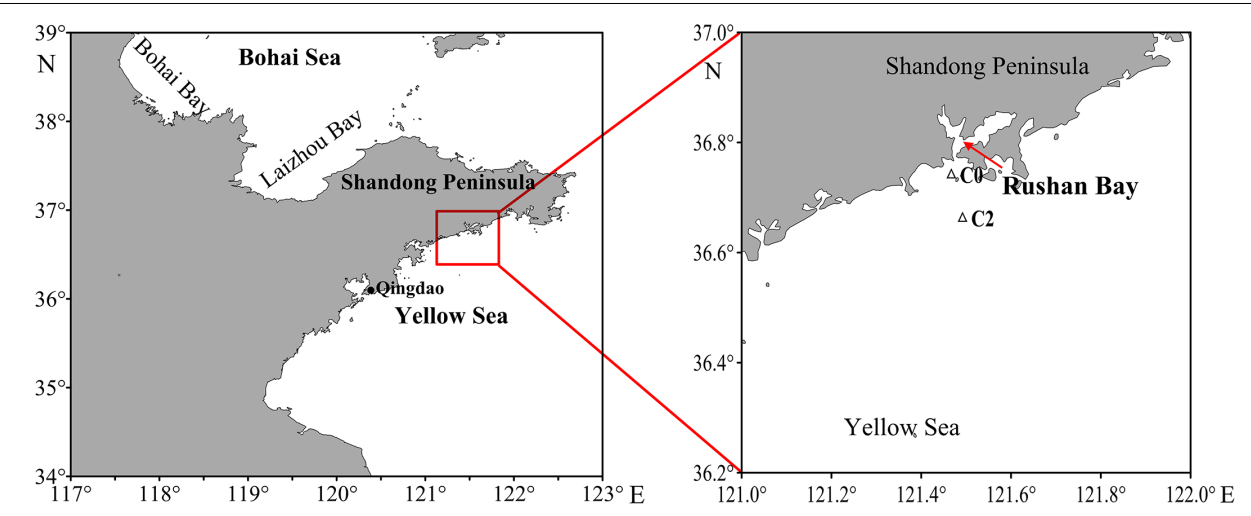

FIGURE 1 | Location of sampling stations in adjacent waters of Rushan Bay, China.

TABLE 1 | The environmental factors at the sampling stations.

\begin{tabular}{|c|c|c|c|c|c|c|c|c|c|}
\hline Sample & Depth (m) & $\mathbf{T}\left({ }^{\circ} \mathrm{C}\right)$ & Sal & $\mathrm{DO}\left(\mathrm{mg} \cdot \mathrm{L}^{-1}\right)$ & Chla $\left(\mu \mathrm{g} \cdot \mathrm{L}^{-1}\right)$ & $\mathrm{NH}_{4}{ }^{+}(\mu \mathrm{M})$ & $\mathrm{NO}_{2}^{-}(\mu \mathrm{M})$ & $\mathrm{NO}_{3}{ }^{-}(\mu \mathrm{M})$ & $\mathrm{PO}_{4}{ }^{3-}(\mu \mathrm{M})$ \\
\hline SCO & 8.9 & 24.71 & 30.79 & 6.00 & 0.10 & 0.56 & 0.26 & 1.74 & 0.11 \\
\hline SC2 & 16.6 & 21.79 & 30.85 & 5.51 & 1.59 & 2.14 & 0.16 & 1.22 & 0.11 \\
\hline WCO & 6.0 & 3.34 & 31.36 & 11.54 & 2.22 & 6.93 & 0.12 & 5.23 & 0.58 \\
\hline WC2 & 13.0 & 3.45 & 31.26 & 10.93 & 3.40 & 5.87 & 0.30 & 4.43 & 0.44 \\
\hline
\end{tabular}

T, temperature; Sal, salinity; DO, dissolved oxygen concentration; Chla, chlorophyll-a content.

et al., 2013). Redundancy analysis (RDA) was employed to explore the correlations between microbial communities and environmental factors with CANOCO for Windows (version 4.5) (ter Braak and Šmilauer, 2002). Pearson's correlation analysis for the abundance, transcript abundance, PNR and environmental factors were performed with SPSS statistics software (version 19.0), and the comparison of PNR among sampling stations and seasons was also archived using SPSS by Bonferroni correction.

\section{Accession Numbers of DNA Sequences}

The raw data generated from pyrosequencing were deposited in the NCBI Sequence Read Archive (SRA) database under accession numbers SRP073125 and SRP073126.

\section{RESULTS}

\section{Environmental Factors at Sampling Stations}

The environmental factors in the bottom water were shown in Table $\mathbf{1}$. The temperature was approximately $21.79-24.71^{\circ} \mathrm{C}$ in summer and decreased to $3.34-3.45^{\circ} \mathrm{C}$ in winter. An OMZ (3.7-7.0 $\left.\mathrm{mg} \cdot \mathrm{L}^{-1}\right)$ was observed in summer at our sampling stations. Salinity, chla and phosphate concentration were higher in winter than in summer. Ammonium and nitrate concentrations were both much higher than those of nitrite in both summer and winter.

\section{amoA Gene Diversity}

The Good's coverage, Chao 1 estimator and Shannon index of AOA and AOB communities are listed in Table 2. The Chao 1 estimator and Shannon index indicated that AOA displayed higher richness and diversity than $\mathrm{AOB}$ at all sampling stations. Individually, AOA had a higher richness and diversity in summer, while $\mathrm{AOB}$ had a higher richness and diversity in winter. For each sample, AOA had the highest diversity at SC0, whereas $\mathrm{AOB}$ had the highest diversity at SC2. The coverage at all samples stations exceeded 0.99, suggesting that the $a m o A$ gene sequences retrieved from these samples could represent the majority of $\mathrm{AOA}$ and $\mathrm{AOB}$ communities.

TABLE 2 | Richness indices, diversity indices and Good's coverage of the AOA and AOB communities.

\begin{tabular}{|c|c|c|c|c|c|c|c|c|}
\hline Sample & \multicolumn{4}{|c|}{ AOA } & \multicolumn{4}{|c|}{ АOB } \\
\hline $\mathrm{SC} 2$ & 41 & 43.7 & 3.73 & 0.99 & 16 & 17 & 2.60 & 1.00 \\
\hline WCO & 38 & 36.8 & 3.68 & 0.99 & 21 & 21 & 2.39 & 0.99 \\
\hline WC2 & 45 & 45.9 & 3.67 & 0.99 & 20 & 20 & 2.44 & 0.99 \\
\hline
\end{tabular}



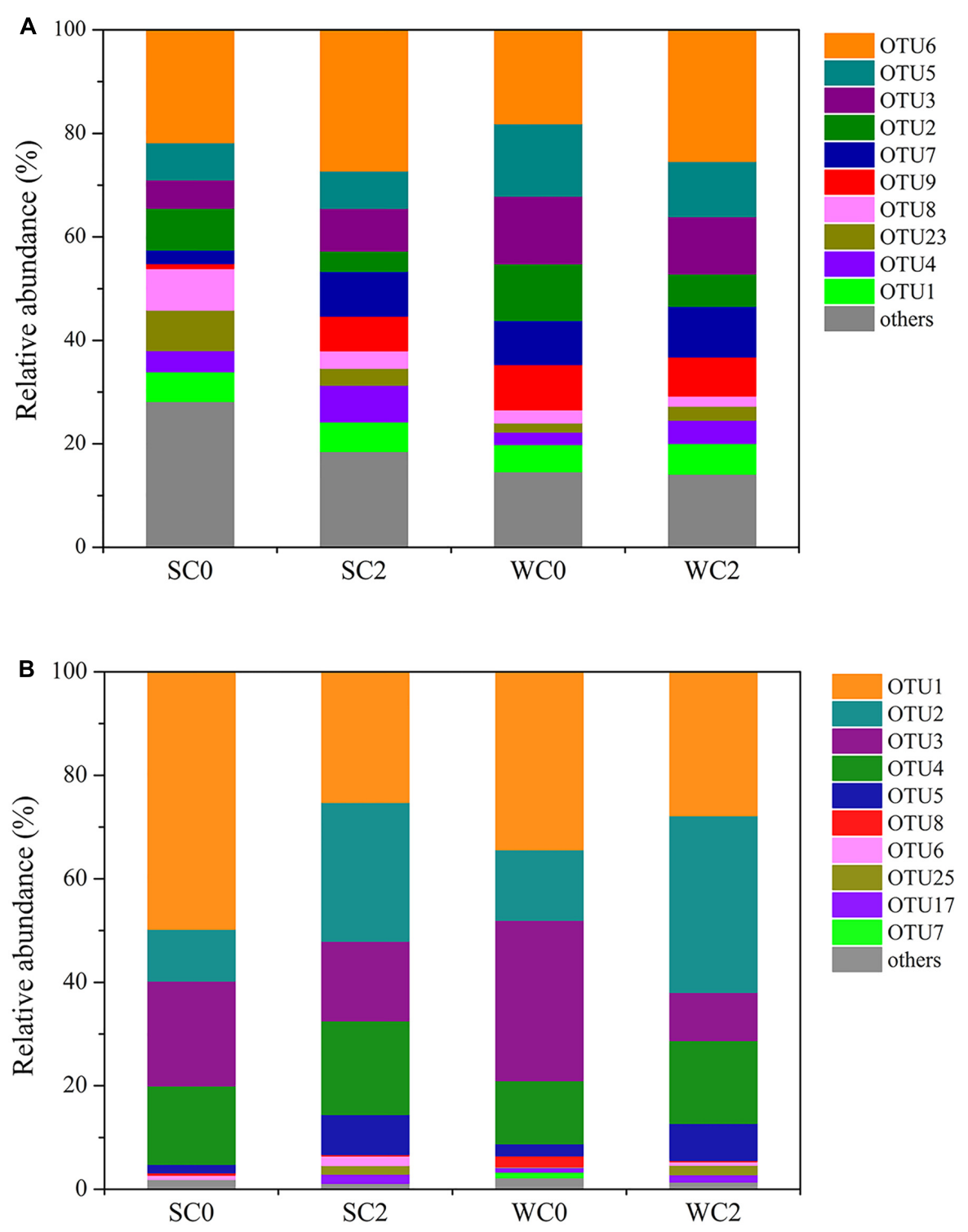

FIGURE 2 | Relative abundance of AOA (A) and AOB (B) OTUs. Only OTUs with relative abundance rankings in the top 10 were analyzed.

\section{AOA and AOB Community Compositions}

Using a 3\% cutoff, 59132 high-quality archaeal amoA gene sequences were clustered into 60 OTUs. Within each sample, the AOA OTU numbers ranged from 38 to 46, with the lowest richness at $\mathrm{WCO}$ and the highest richness at SC0. The compositions of OTUs in the AOA communities are shown in Figure 2A, and only one predominant OTU (OTU6) was found. This result implies that AOA communities are generally ubiquitous and may be less influenced by environmental conditions.

The neighbor-joining tree indicated that the AOA community was classified into two major groups in this study: Nitrosopumilus and Nitrososphaera (Figure 3A). Most of archaeal amoA gene sequences (more than $98.97 \%$ in each sample) fell within the Nitrosopumilus group. Only four OTUs were affiliated with the
Nitrososphaera group, which was a subset of the soil/sediment cluster, and this group reached an abundance of 1.03, 0.13, 0.32, and $0.33 \%$ at SC0, SC2, WC0 and WC2, respectively (Figure 4A).

Regarding $\mathrm{AOB}, 43131$ high-quality bacterial amo $A$ gene sequences were grouped into 32 OTUs using the $3 \%$ cutoff. Within each sample, the AOB OTU numbers ranged from 16 to 21, with the lowest richness at SC2 and the highest richness at WC0. We discovered several predominant OTUs (Figure 2B), and the predominant OTU at each station was identical in summer and winter, with OTU1 at C0 and OTU2 at C2. Therefore, the dominant AOB species might change with environmental conditions, consistent with a previous study indicating that $\mathrm{AOB}$ could be used as an indicator of specific environmental conditions (Olsson et al., 2006; He et al., 2007). 

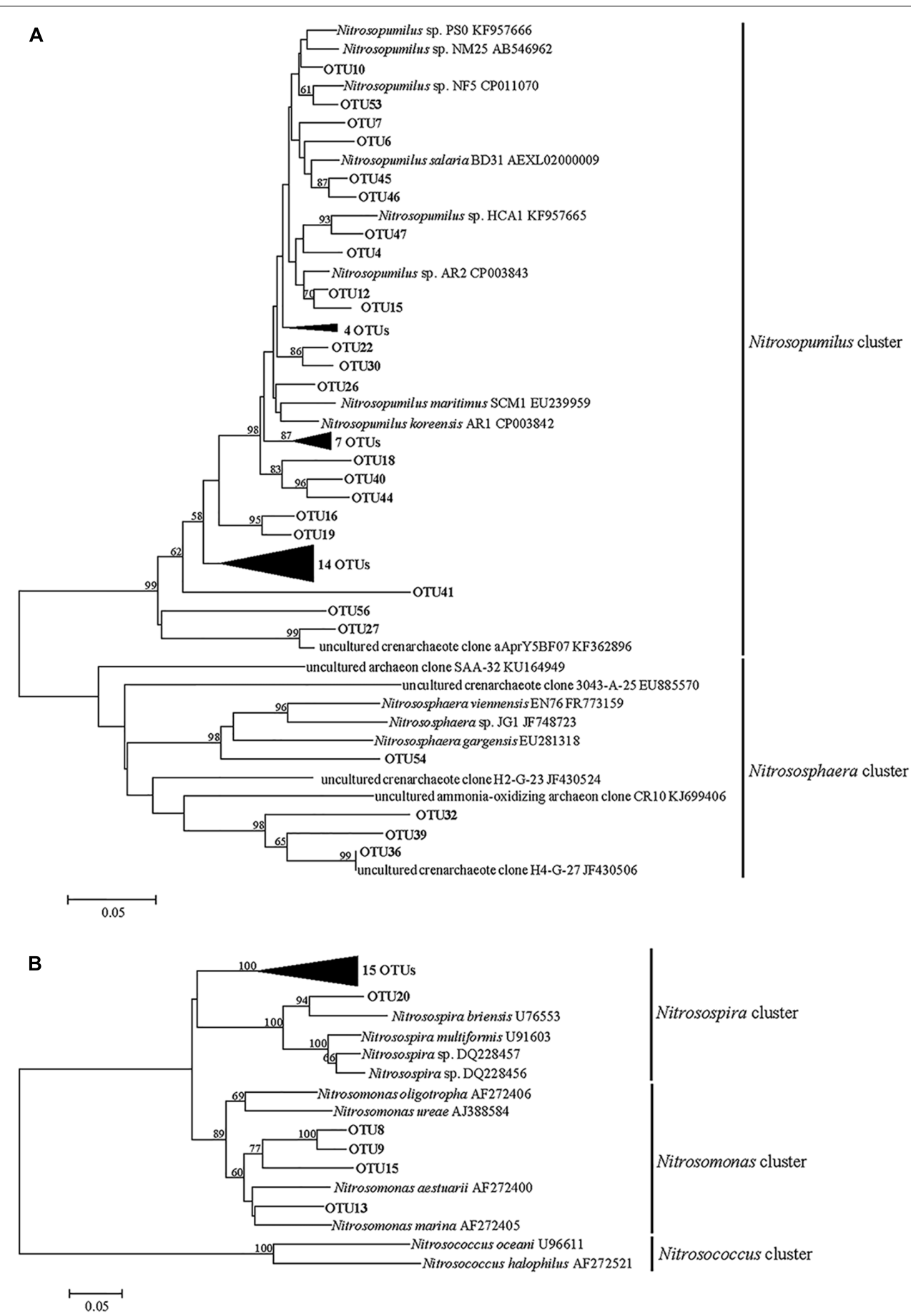

FIGURE 3 | Neighbor-joining phylogenetic tree of archaeal (A) and bacterial (B) amoA gene sequences. Bootstrap values greater than $50 \%$ of 1000 resamplings are shown near nodes. The scale bar indicates 0.05 nucleotide substitutions per nucleotide position.

Phylogenetic analysis showed that the AOB community was divided into the Nitrosospira group and Nitrosomonas group (Figure 3B). More than $97.11 \%$ of the bacterial amoA gene sequences fell within the Nitrosospira group, suggesting a significant role of Nitrosospira in the studied sediments. Compared with the Nitrosospira group, the Nitrosomonas group reached an abundance of $2.09,0.48,2.89$, and $0.49 \%$ at $\mathrm{SC} 0$, $\mathrm{SC} 2, \mathrm{WC} 0$ and $\mathrm{WC} 2$, respectively, and the proportion of the Nitrosomonas group was greater at station C0 than at station C2 in both summer and winter (Figure 4B).

The variations in $\mathrm{AOA}$ and $\mathrm{AOB}$ communities were analyzed using UPGMA clustering. SC0 formed a single branch, and 


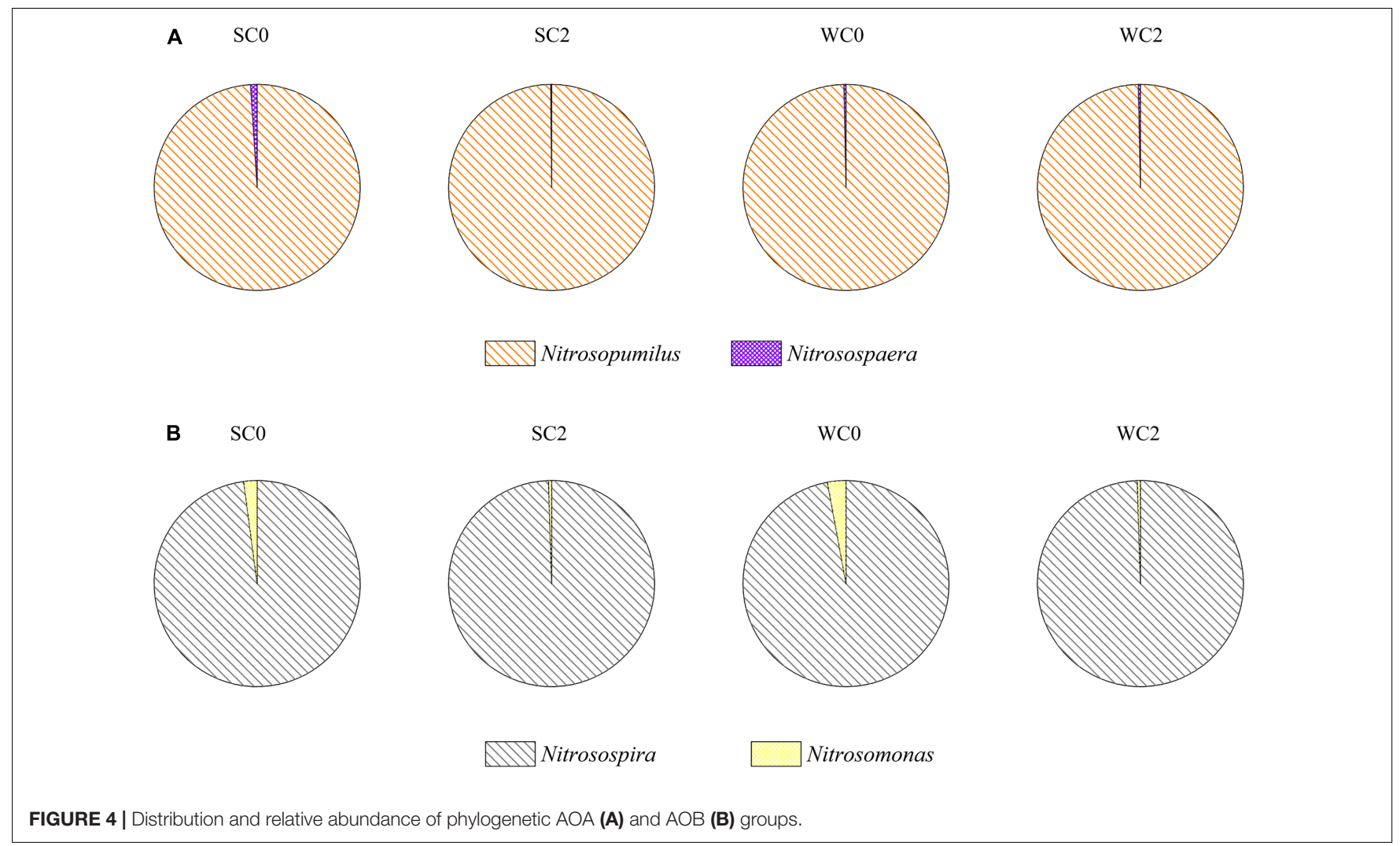

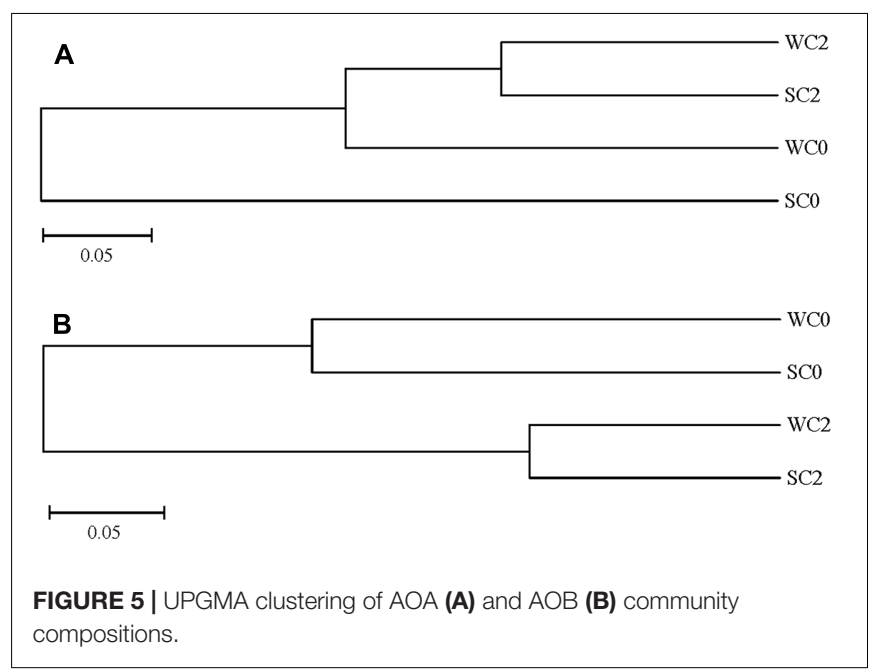

the other stations formed a branch, indicating that not only geographic locations but also seasons play a significant role in AOA community compositions (Figure 5A). For the AOB community, the UPGMA cluster tree showed that the AOB communities at station $\mathrm{C} 0$ were separately clustered from those at station C2 (Figure 5B), and it can be speculated that compared with the differences in seasons, different geographic locations had a greater effect on $\mathrm{AOB}$ community compositions. Our results also indicated that different seasons had a greater effect on the AOA community than on the AOB community.

\section{Impact of Environmental Factors on AOA and $\mathrm{AOB}$ Communities}

The impact of environmental factors on $\mathrm{AOA}$ and $\mathrm{AOB}$ communities were determined via RDA. The OTUs of AOA and $\mathrm{AOB}$ communities were square root transformed and then used as species data for RDA analysis. The correlation was demonstrated by calculating the cosine value between the environmental factors and axes. BIOENV identified that temperature, salinity and ammonium concentration most strongly correlated with AOA communities, while temperature, chla and nitrite concentration most strongly correlated with $\mathrm{AOB}$ communities. The first two RDA dimensions explained $95.2 \%$ of the variation in the AOA community (Figure 6A). The first axis had the positive correlation with temperature $(r=0.7025)$ and negative correlation with salinity $(r=-0.7405)$ and ammonium concentration $(r=-0.9272)$. Thus, RDA analysis revealed that the AOA community was positively correlated with temperature and negatively with salinity and ammonium concentration. As for $\mathrm{AOB}$, the first two axes represented $94.3 \%$ of the variation (Figure 6B). The first axis had the positive correlation with chla $(r=0.6922)$; for the second axis, it had the negative correlation with temperature $(r=-0.6641)$ and nitrite concentration $(r=-0.7701)$. Therefore, it was speculated that chla contributed greatly to the AOB community, followed by nitrite concentration and temperature. However, Monte Carlo permutations showed that none of the environmental factors significantly influenced AOA or AOB communities $(P>0.05$, 499 Monte Carlo permutations). 

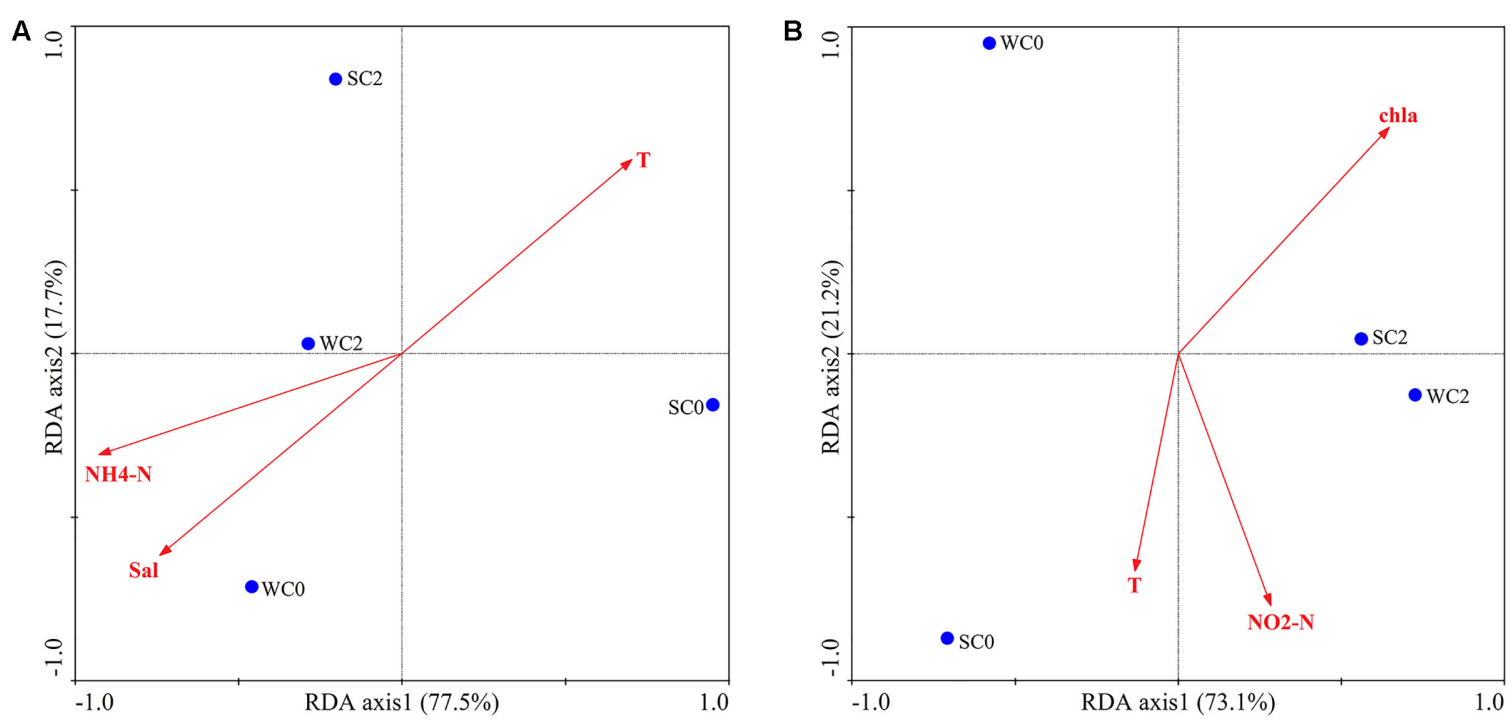

FIGURE 6 |RDA ordination plots for the relationships between AOA (A) and AOB (B) communities and environmental factors.

\section{Abundance of amoA Genes}

The reliability of the qPCR assay with both primers was confirmed by the strong linear inverse relationship between the threshold cycle value $\left(\mathrm{C}_{\mathrm{t}}\right)$ and the logarithmic value of the gene copy numbers $\left(R^{2}>0.99\right)$. Only one observable peak at the melting temperature $\left(78.0^{\circ} \mathrm{C}\right.$ for $\mathrm{AOA}$ and $79.3^{\circ} \mathrm{C}$ for $\left.\mathrm{AOB}\right)$ was found. In addition, no primer-dimer artifacts or other nonspecific PCR products were observed.

The abundance and the transcript abundance of archaeal and bacterial amoA genes was determined via qPCR (Figure 7). The amplification efficiencies were $81.69 \%$ for AOA and $99.54 \%$ for AOB. The abundance of archaeal amoA genes (ranging from $1.33 \times 10^{8}$ to $2.18 \times 10^{8}$ copies. $g^{-1}$ ) was $1-2$ orders of magnitude greater than that of bacterial amoA genes (ranging from $8.38 \times 10^{6}$ to $4.80 \times 10^{7}$ copies. $\mathrm{g}^{-1}$ ). Correlation analysis showed that no environmental factors appeared to contribute significantly to the abundance of archaeal or bacterial amoA genes $(P>0.05)$.

The transcript abundance of archaeal $a m o A$ gene (ranging from $1.15 \times 10^{4}$ to $1.03 \times 10^{5}$ copies. $\mathrm{g}^{-1}$ ) was also greater than that of bacterial amoA gene (ranging from $1.53 \times 10^{3}$ to $2.63 \times 10^{4}$ copies. $\mathrm{g}^{-1}$ ). The average transcript abundance of archaeal $a m o A$ was $8.37 \times 10^{4}$ and $1.62 \times 10^{4}$ copies. $g^{-1}$ during summer and winter, respectively, and the average transcript abundance of bacterial amoA was also greater in summer than in winter, demonstrating that the ammonia oxidation process was more active during the summer. Based on the correlation analysis, temperature, chla and ammonium concentration were significantly related to the transcript abundance of archaeal amoA genes $(P<0.05)$.

\section{Potential Nitrification Rates}

PNR in surface sediments from adjacent waters of Rushan Bay had significant seasonal variations (Figure 8A). Total

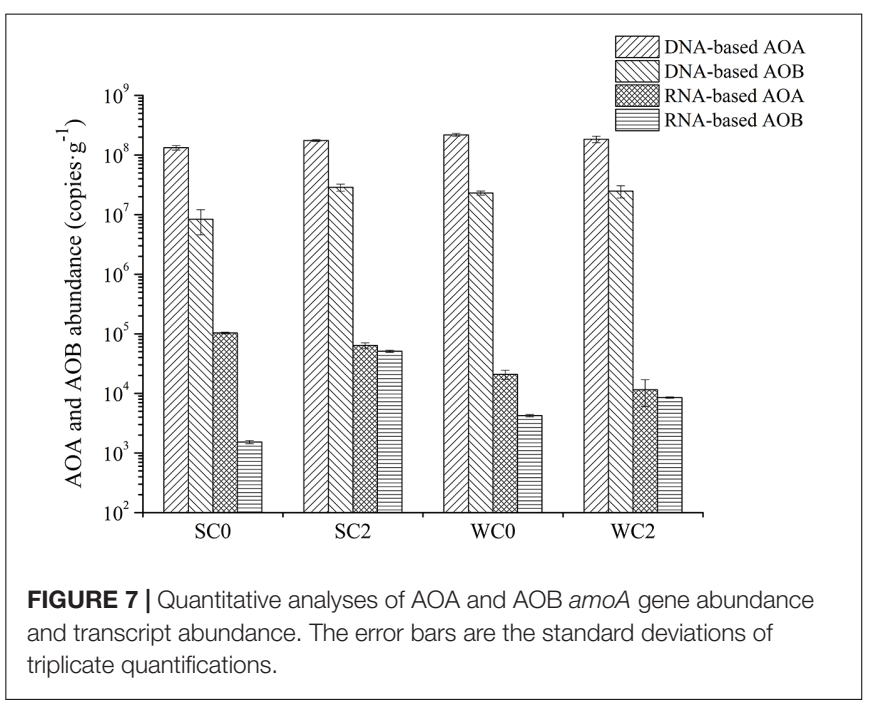

PNR in summer was $0.95-1.03 \mu \mathrm{mol} \mathrm{N} \cdot \mathrm{g}^{-1} \cdot \mathrm{day}^{-1}$, which was significantly greater than that in winter. The addition of ampicillin to separate the PNR of AOA from total PNR revealed that the PNR of AOA was much higher in winter, whereas the PNR of AOB was greater in summer. For total PNR and the PNR of AOB, a significant variation was observed among seasons $(P<0.05)$. However, sampling sites had no significant effect on total PNR, the PNR of AOA or the PNR of AOB $(P>0.05)$. Temperature, salinity, dissolved oxygen concentration, ammonium concentration, nitrate concentration and phosphate concentration had significant effects on the total PNR and PNR of AOB $(P<0.05)$, whereas a strong correlation was found between chla and PNR of AOA $(P<0.05)$. However, neither the amoA gene abundance nor its transcript abundance was significantly related to PNR in this study $(P>0.05)$. 
Significant seasonal variations were detected in the relative contributions of $\mathrm{AOA}$ and $\mathrm{AOB}$ to ammonia oxidation (Figure 8B). The relative contribution of AOA in winter ranged from 59.07 to $72.79 \%$ and was significantly greater than that in summer. In contrast to $\mathrm{AOA}$, the relative contribution of $\mathrm{AOB}$ was greater in summer, and the relative contribution of AOB in winter ranged only from 27.21 to $40.93 \%$. Temperature, salinity and dissolved oxygen concentration had significant effects on the relative contribution of $\mathrm{AOA}$ and $\mathrm{AOB}$ to ammonia oxidation. Correlation analysis indicated that temperature was negatively related to the relative contribution of AOA $(P<0.05)$ but positively related to the relative contribution of AOB $(P<0.05)$. Salinity and dissolved oxygen concentration were significantly positively related to the relative contribution of AOA $(P<0.05)$ but negatively related to the relative contribution of $\mathrm{AOB}$ $(P<0.05)$.

\section{DISCUSSION}

Currently, most studies have used a cloning-sequencing method rather than a pyrosequencing method to examine $\mathrm{AOA}$ and $\mathrm{AOB}$ communities, and only a few studies have used pyrosequencing to describe amoA diversity (Pester et al., 2012; Mao et al., 2013; Hayashi et al., 2015; Tago et al., 2015; Zhang et al., 2016). In the present study, the community structure, diversity and activity of ammonia oxidizers were researched to understand the community information, the different contributions of $\mathrm{AOA}$ and $\mathrm{AOB}$ to ammonia oxidation and the impact of environmental factors on community composition in surface sediments from adjacent waters of Rushan Bay. AOB had a lower diversity than AOA, consistent with results from other coastal environments (Santoro et al., 2008; Cao et al., 2011b; Jin et al., 2011). Studies have identified that the diversity of AOA in estuaries might be greater than that in the adjacent open oceans, which may be due to nutrients in the river discharge (Llyd and Jody, 2003; Cao et al., 2011a). In the present study, the diversity of $\mathrm{AOA}$ at $\mathrm{C} 0$ was relatively greater than that at $\mathrm{C} 2$, consistent with the above view. Environmental factors, such as temperature, salinity, nitrate concentration and total nitrogen, were considered as driving forces affecting the diversity of $\mathrm{AOA}$ or $\mathrm{AOB}$ communities (Bernhard et al., 2005; Cao et al., 2011a; Yu et al., 2016). However, according to the correlation analysis, no noticeable environmental factors could be identified in relation to the diversity of AOA or AOB communities in our studied sediments $(P>0.05)$.

Phylogenetic analysis indicated that the AOA community was clustered into the Nitrosopumilus group and Nitrososphaera group (Figure 3A). A clear separation of AOA communities between marine and terrestrial environments was observed in our study, in accordance with a study of eastern intertidal sediments in Chongming Island (Zheng et al., 2013). The presence of soilrelated AOA in our studied sediments could be explained by the deposition of microorganisms from upstream water with runoff, consistent with the greater relative abundance of Nitrososphaera group at $\mathrm{C} 0$ in both summer and winter (Figure 4A). The core microbiome of AOA communities exhibited greater similarity to the uncultured archaeal amoA gene sequences from other environments, such as the North Sea (Lipsewers et al., 2014), Tanoura Bay (Ando et al., 2009), Elkhorn Slough estuary (Wankel et al., 2011) and Eastern China Marginal Seas (Yu et al., 2016), showing that AOA obtained in this study was not representative of the special group in the studied sediments and their genotypes are ubiquitous worldwide.

The bacterial amoA sequences recovered from our studied areas were classified into the Nitrosospira group and Nitrosomonas group (Figure 3B). The Nitrosospira group accounted for most of $\mathrm{AOB}$ in our study, whereas the Nitrosomonas group showed lower relative abundance of $2.09,0.48,2.89$, and $0.49 \%$ at SC0, SC2, WC0 and WC2, respectively (Figure $4 \mathrm{~B}$ ). The proportions of the Nitrosomonas group were greater at SC0 and $\mathrm{WC} 0$, suggesting that the upstream water has a significant impact on marine benthic microbes (Dang et al., 2008). Freitag et al. (2006) found that the Nitrosospira group dominated at stations with a marine
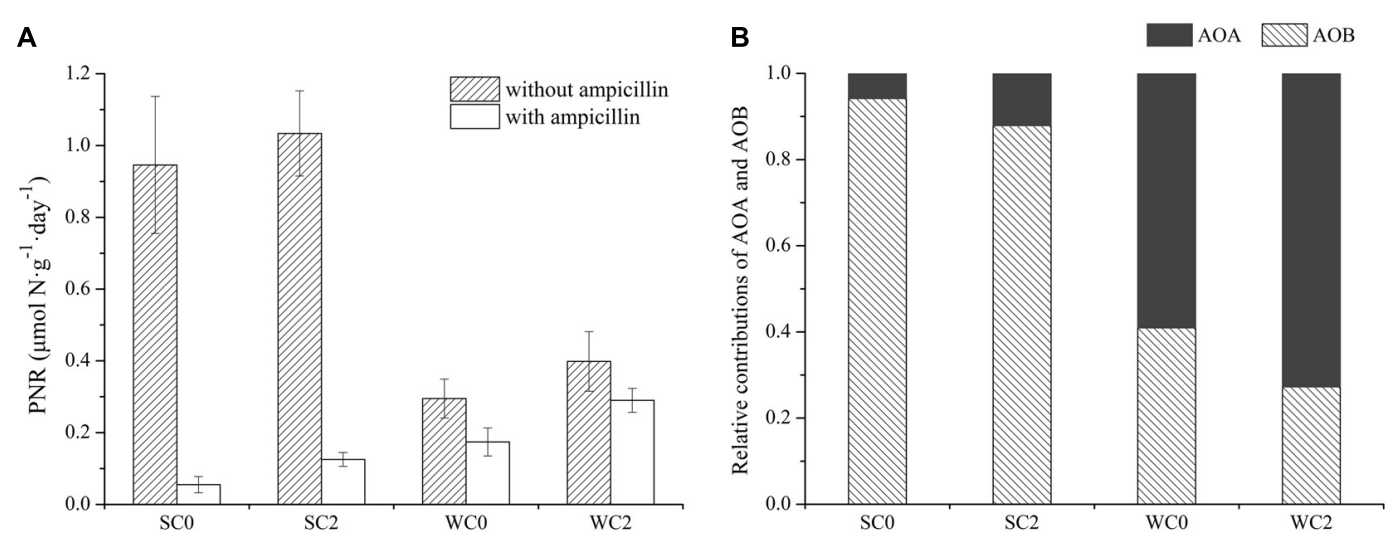

FIGURE 8 | Potential nitrification rates (PNR) analyses in surface sediments from adjacent waters of Rushan Bay. (A) PNR in surface sediments from adjacent waters of Rushan Bay incubated with and without ampicillin. The error bars are the standard deviations of triplicate incubations. (B) The relative contributions of AOA and AOB to ammonia oxidation. 
influence, while the Nitrosomonas group had an advantage at stations with a freshwater influence. This evidence indicated that the Nitrosospira group may be more adaptable than the Nitrosomonas group in the coastal marine area, consistent with our results.

Various environmental factors can impact $\mathrm{AOA}$ and $\mathrm{AOB}$ communities, and their effects may be complicated. As the primary energy source of ammonia oxidizers, ammonium concentration is considered to be a vital factor influencing the ammonia oxidizers' community structure. In a study of AOA communities in mangrove sediments, Li et al. (2010) demonstrated that ammonium concentrations might negatively impact the diversity of AOA. Ammonium concentrations were also found to be an important element for the community structure of $\mathrm{AOB}$ in intertidal sediments of Yangtze estuary (Zheng et al., 2014). Although AOB was sensitive to dissolved oxygen concentrations, studies have shown that dissolved oxygen concentrations can affect the activity of $\mathrm{AOB}$ rather than the AOB community (Park et al., 2008). Thus, no relationship between dissolved oxygen concentrations and the AOB community was found in the present study. RDA analysis indicated that temperature, salinity and ammonium concentration were the most important factors affecting the AOA community composition (Figure 5A), whereas temperature, chla and nitrite concentration appeared to play a pivotal role in the AOB community composition (Figure 5B). These factors have already been previously reported to be important for the determination of AOA and AOB communities (Sahan and Muyzer, 2008; Bouskill et al., 2012). Moreover, RDA indicated that no single environmental factor was likely to completely determine the AOA or AOB community compositions $(P>0.05,499$ Monte Carlo permutations), and the ammonia oxidizers' community structure in the present study seemed to be influenced by several environmental factors in combination, possibly due to a variety of nature environmental gradients and multicollinearity among many abiotic factors in coastal estuarine regions.

The amoA gene obtained in the present study and other five pyrosequencing studies (sediments from Changjiang Estuary and Hangzhou Bay, soils from Minami-Daito Island and NyÅlesund) (Hayashi et al., 2015; Tago et al., 2015; Xia et al., 2015; Zhang et al., 2015, 2016) were trimmed as reported above. The remaining high-quality sequences were clustered into 280 OTUs (for AOA) and 201 OTUs (for AOB) at 97\% similarity levels. UPGMA clustering of the samples from the five environments was conducted using the $\mathrm{R}$ program. The UPGMA cluster showed a clear separation of AOA and AOB communities in samples from these five environments. The community types of AOA were clustered into three different groups consisting of group I, group II and group III (Figure 9A). The environment samples from Rushan Bay (RSB), Changjiang Estuary (CJE) and Hangzhou Bay (HZB) showed marine characteristics and were grouped together, while the other two soil samples formed group II and group III. Therefore, we speculated that geography contributes significantly to the community structure of AOA, consistent with reports showing that diverse and distinct AOA communities are associated with each habitat (Francis et al., 2005; Dang et al., 2009). Furthermore, similar to the UPGMA clustering of AOA communities, the $\mathrm{AOB}$ communities were clustered into two different groups according to the sediment and soil habitats (Figure 9B). The environment samples from RSB, CJE and HZB, which showed marine characteristics, were grouped together. The AOB community from soils in MinamiDaito Island (MD) appeared to be more similar to that in Ny-Ålesund (NA), although they are far from each other geographically. Many studies have shown that AOB communities are dominated by Nitrosomonas in terrestrial environments, whereas in estuarine areas, Nitrosospira may be more adaptable (Bartosch et al., 2002; Dang et al., 2010; Cao et al., 2011a). Based on all of these results, we can speculate that geography also contributes significantly to the community structure of AOB. The difference in geography mainly reflects differences in environmental conditions. Thus, the role of geography in the ammonia oxidizers' community structure essentially depends on different environmental factors, for instance, ammonium concentration, salinity and temperature.

Consistent with most reports, our study showed that AOA was more abundant than AOB (Liu et al., 2011; Yao et al., 2011; Sims et al., 2012a,b; Hou et al., 2013b). Environmental factors, for instance, salinity, temperature and ammonium concentration, have been identified as potential factors to determine the abundance of AOA and $\mathrm{AOB}$. In our study, correlation analysis indicated that no single environmental factor was likely to completely determine the ammonia oxidizers' abundance, which seemed to be influenced by a combination of factors. The abundance of amoA gene could provide information concerning the potential ammonia-oxidizing activity, while the transcript activity of the $a m o A$ gene is a measure of protein production. In the studied sediments, both the ratios of active AOA to total $\mathrm{AOA}$ and the ratios of active $\mathrm{AOB}$ to total $\mathrm{AOB}$ were less than $1 \%$, which indicated that most of the AOA and $\mathrm{AOB}$ $a m o A$ genes are likely associated with inactive cells. Studies have shown that external ammonium concentrations can up-regulate the expression of the amo operon. For example, in Nitrosomonas europaea, the proximal amoCAB promoter is active only when recovery from ammonium starvation, while the distal amoCAB promoter is constitutively active in the presence of ammonium (Berube et al., 2007). Our finding that the transcript abundance of the archaeal amoA gene peaked in the lowest ammonium concentration region was consistent with previous findings. To regulate the archaeal $a m o A$ gene transcription, temperature is another critical element (Tourna et al., 2008). Greater archaeal amo $A$ transcript abundances were observed in warmer seawaters in our studied sediments, but no significant relationship was observed between archaeal amoA transcripts and temperature $(P>0.05)$.

Potential nitrification rates can reflect potential ammoniaoxidizing activity. There may be some certain connections between PNR and the abundance of ammonia oxidizers; however, the relationships did not achieve significant levels in our study $(P>0.05)$. Many environmental factors, such as salinity, ammonia concentration, dissolved oxygen concentration and temperature, can impact PNR. In the present study, there was a strong negative correlation between the total PNR and salinity, indicating that a high level of salinity could inhibit 


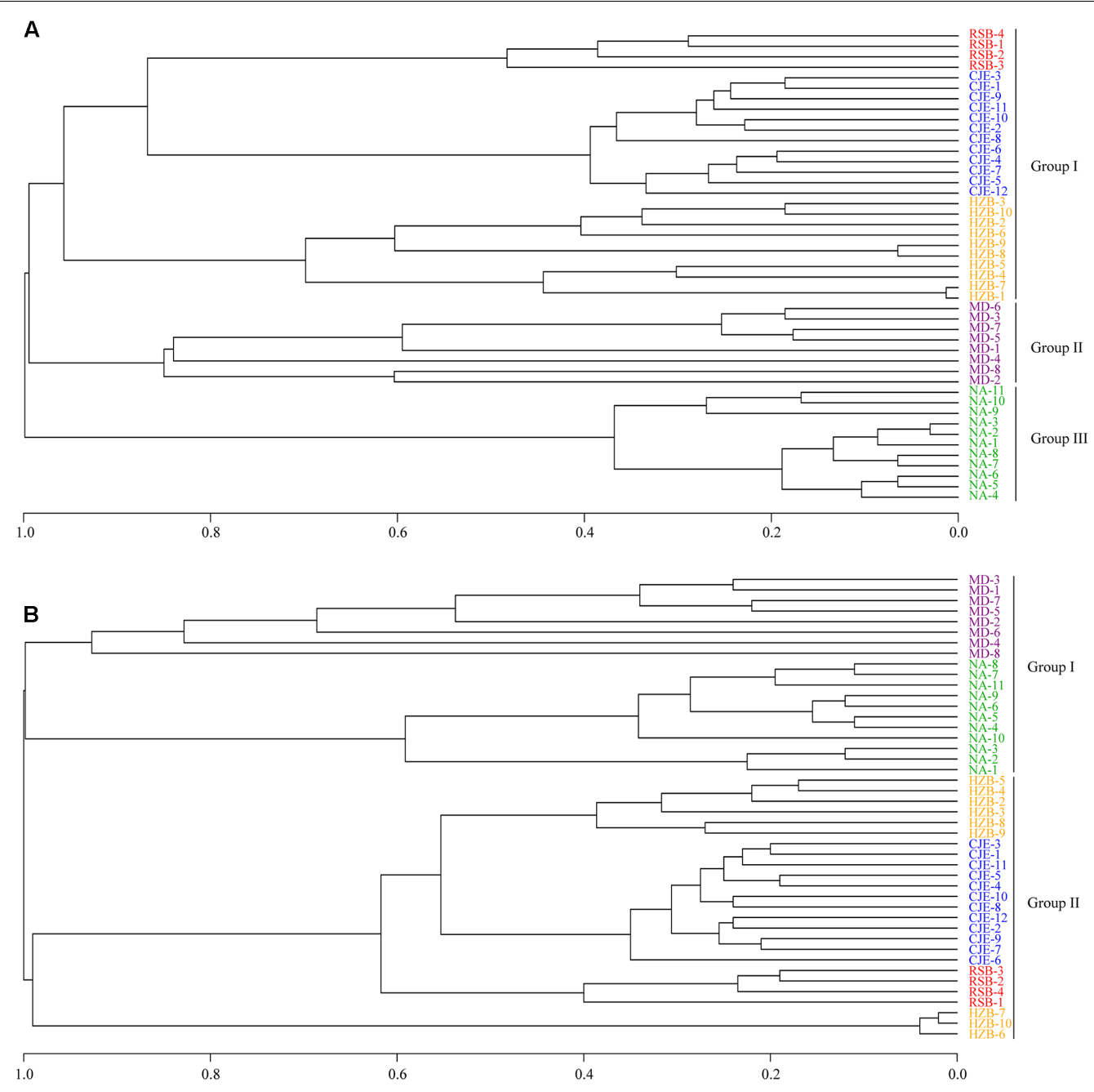

FIGURE 9 | UPGMA clustering of AOA (A) and AOB (B) community compositions in previous studies and in the present study. RSB-*, CJE-*, HZB-*, MD-*, and NA-* indicate sequences from this study, Changjiang Estuary (Xia et al., 2015), Hangzhou Bay (Zhang et al., 2015, 2016), Minami-Daito Island (Hayashi et al., 2015) and Ny-Ålesund (Tago et al., 2015), respectively.

the metabolic activity of ammonia oxidizers. In addition, the total PNR also showed a strong positive correlation with temperature, which could explain why the total PNR were higher in summer. In addition to the total PNR, the PNR of AOB and temperature also showed a significant positive correlation $(P<0.01)$. All previously identified AOB are mesophilic bacteria, and their optimum growth temperature usually ranges from $20^{\circ} \mathrm{C}$ to $30^{\circ} \mathrm{C}$ ( $\mathrm{Yu}$ et al., 2015). Temperature can directly affect the nitrification activity of $\mathrm{AOB}$, which peaks at $15^{\circ} \mathrm{C}$ to $25^{\circ} \mathrm{C}$ (Avrahami et al., 2003). Enzyme activity decreases with decreasing temperature, ultimately resulting in a decline in the nitrification activity of $\mathrm{AOB}$ in winter. In contrast to $\mathrm{AOB}, \mathrm{AOA}$ has a wide tolerance to temperature (Schleper et al., 2005; Jiang et al., 2010), and thus AOA shows an obvious competitive advantage over $\mathrm{AOB}$ at a high or low temperature.

Although the abundance and transcript abundance of AOA were greater than that of $\mathrm{AOB}$ in both summer and winter, the PNR of $\mathrm{AOB}$ and $\mathrm{AOA}$ was greater in summer and winter, respectively, leading us to hypothesize that PNR is directly related to nitrification potentials and the transcript abundance of ammonia oxidizers. Studies have shown that the nitrification potentials of $\mathrm{AOB}$ are 1-3 times as many as AOA (Jia and Conrad, 2009). Temperature was one of the important factors affecting nitrification potentials in this study $(P<0.05)$. The seasonal variation of the nitrification potentials directly led to the seasonal differences in the relative contributions of $\mathrm{AOA}$ and $\mathrm{AOB}$ to ammonia oxidation. The nitrification potentials of $\mathrm{AOB}$ decreased during winter, and AOB's transcript abundance was relative lower. Thus, AOA dominated ammonia oxidation in surface sediments from adjacent waters of Rushan Bay. In summer, AOA had a greater transcript abundance than $\mathrm{AOB}$, while $\mathrm{AOB}$ had far higher nitrification potentials than AOA. Thus, AOB contributed significantly to ammonia oxidation in surface sediments from adjacent waters of Rushan Bay. 


\section{CONCLUSION}

In general, in surface sediments from adjacent waters of Rushan Bay, the diversity of AOA was higher than that of AOB. Nitrosopumilus group of AOA and Nitrosospira group of $\mathrm{AOB}$ may be more adaptable in the studied sediments. Both the abundance and the transcript abundance of AOA were greater than those of $\mathrm{AOB}$, and most $\mathrm{AOA}$ and $\mathrm{AOB}$ amoA genes are likely associated with inactive cells. Significant seasonal variations were observed in PNR, and $\mathrm{AOA}$ and $\mathrm{AOB}$ contributed differentially to ammonia oxidation in different seasons. AOB occupied the dominant position in mediating ammonia oxidation during summer, while AOA might be dominant in ammonia oxidation during winter.

\section{AUTHOR CONTRIBUTIONS}

$\mathrm{HH}, \mathrm{YZ}$, TM, and ZY designed the experiments. HH and LF performed the experiments and analyzed the data. $\mathrm{HH}$ and $\mathrm{YZ}$ wrote the paper.

\section{REFERENCES}

Ando, Y., Nakagawa, T., Takahashi, R., Yoshihara, K., and Tokuyama, T. (2009). Seasonal changes in abundance of ammonia-oxidizing archaea and ammoniaoxidizing bacteria and their nitrification in sand of an eelgrass zone. Microbes. Environ. 25, 21-27. doi: 10.1264/jsme2.ME08536

Auguet, J. C., Nomokonova, N., Camarero, L., and Casamayor, E. O. (2011). Seasonal changes of freshwater ammonia-oxidizing archaeal assemblages and nitrogen species in oligotrophic alpine lakes. Appl. Environ. Microbiol. 77, 1937-1945. doi: 10.1128/AEM.01213-10

Avrahami, S., Werner, L., and Ralf, C. (2003). Effects of temperature and fertilizer on activity and community structure of soil ammonia oxidizers. Environ. Microbiol. 5, 691-705. doi: 10.1046/j.1462-2920.2003.00457.x

Bartosch, S., Hartwig, C., Spieck, E., and Bock, E. (2002). Immunological detection of Nitrosospira-like bacteria in various soils. Microb. Ecol. 43, 26-33. doi: 10.1007/s00248-001-0037-5

Beman, J. M., Bertics, V. J., Braunschweiler, T., and Wilson, J. M. (2012). Quantification of ammonia oxidation rates and the distribution of ammoniaoxidizing archaea and bacteria in marine sediment depth profiles from Catalina Island, California. Front. Microbiol. 3:263. doi: 10.3389/fmicb.2012.00263

Bernhard, A. E., Donn, T., Giblin, A. E., and Stahl, D. A. (2005). Loss of diversity of ammonia-oxidizing bacteria correlates with increasing salinity in an estuary system. Environ. Microbiol. 7, 1289-1297. doi: 10.1111/j.14622920.2005.00808.x

Bernhard, A. E., Tucker, J., Giblin, A. E., and Stahl, D. A. (2007). Functionally distinct communities of ammonia-oxidizing bacteria along an estuarine salinity gradient. Environ. Microbiol. 9, 1439-1447. doi: 10.1111/j.1462-2920.2007. 01260.x

Berube, P. M., Samudrala, R., and Stahl, D. A. (2007). Transcription of all amoC copies is associated with recovery of Nitrosomonas europaea from ammonia starvation. J. Bacteriol. 189, 3935-3944. doi: 10.1128/JB.01861-06

Besaury, L., Ghiglione, J. F., and Quillet, L. (2014). Abundance, activity, and diversity of archaeal and bacterial communities in both uncontaminated and highly copper-contaminated marine sediments. Mar. Biotechnol. 16, 230-242. doi: 10.1007/s10126-013-9542-z

Bouskill, N. J., Eveillard, D., Chien, D., Jayakumar, A., and Ward, B. B. (2012). Environmental factors determining ammonia-oxidizing organism distribution and diversity in marine environments. Environ. Microbiol. 14, 714-729. doi: 10.1111/j.1462-2920.2011.02623.x

Caffrey, J. M., Bano, N., Kalanetra, K., and Hollibaugh, J. T. (2007). Ammonia oxidation and ammonia-oxidizing bacteria and archaea from estuaries with

\section{FUNDING}

This work was supported by the National Natural Science Foundation of China (No. 41620104001), the Scientific and Technological Innovation Project of the Qingdao National Laboratory for Marine Science and Technology (2016ASKJ02) and the Open Fund of CAS KLMEES and QNLM LMEES (KLMEES201601).

\section{ACKNOWLEDGMENTS}

We are grateful to Dr. Xianbin Ran, Dr. Jun Liu, and Hualong Wang for assistance with the collection of samples and geochemical data during the cruises. We thank Wenyan Gu for analyzing the ammonium, nitrite and nitrate concentrations in the potential nitrification incubation. We also thank the Marine Ecology Research Center of the First Institute of Oceanography, State Oceanic Administration, People's Republic of China for the determination of environmental factors.

differing histories of hypoxia. ISME J. 1, 660-662. doi: 10.1038/ismej. 2007.79

Cao, H. L., Hong, Y. G., Li, M., and Gu, J. D. (2011a). Diversity and abundance of ammonia-oxidizing prokaryotes in sediments from the coastal Pearl River estuary to the South China Sea. Anton. Leeuw. 100, 545-556. doi: 10.1007/ s10482-011-9610-1

Cao, H. L., Li, M., Hong, Y. G., and Gu, J. D. (2011b). Diversity and abundance of ammonia-oxidizing archaea and bacteria in polluted mangrove sediments. Syst. Appl. Microbiol. 34, 513-523. doi: 10.1016/j.syapm.2010.11.023

Cui, Z. S., Wang, S. L., Zang, J. Y., and Ran, X. B. (2012). Bacterial diversity in an offshore low dissolved oxygen content area contiguous to Rushan Bay. Adv. Mar. Sci. 30, 369-379. doi: 10.3969/j.issn.1671-6647.2012.03.007

Dang, H., Li, J., Zhang, X., Li, T., Tian, F., and Jin, W. (2009). Diversity and spatial distribution of amoA-encoding archaea in the deep-sea sediments of the tropical west pacific continental margin. J. Appl. Microbiol. 106, 1482-1493. doi: 10.1111/j.1365-2672.2008.04109.x

Dang, H. Y., Li, J., Chen, R. P., Wang, L., Guo, L. Z., Zhang, Z. N., et al. (2010). Diversity, abundance, and spatial distribution of sediment ammoniaoxidizing betaproteobacteria in response to environmental gradients and coastal eutrophication in Jiaozhou Bay, China. Appl. Environ. Microbiol. 76, 4691-4702. doi: 10.1128/AEM.02563-09

Dang, H. Y., Zhang, X. X., Sun, J., Li, T. G., Zhang, Z. N., and Yang, G. P. (2008). Diversity and spatial distribution of sediment ammonia-oxidizing crenarchaeota in response to estuarine and environmental gradients in the Changjiang estuary and East China Sea. Microbiology 154, 2084-2095. doi: 10.1099/mic.0.2007/013581-0

de Gannes, V., Eudoxie, G., Dyer, D. H., and Hickey, W. J. (2012). Diversity and abundance of ammonia oxidizing archaea in tropical compost systems. Front. Microbiol. 3:244. doi: 10.3389/fmicb.2012.00244

de Gannes, V., Eudoxie, G., and Hickey, W. J. (2014). Impacts of edaphic factors on communities of ammonia-oxidizing archaea, ammonia-oxidizing bacteria and nitrification in tropical soils. PLOS ONE 9:e89568. doi: 10.1371/journal.pone. 0089568

De Souza, M. P., Chu, A., Zhao, M., Zayed, A. M., Ruzin, S. E., Schichnes, D., et al. (1999). Rhizosphere bacteria enhance selenium accumulation and volatilization by India Mustard. Plant Physiol. 119, 565-574. doi: 10.1104/pp.119.2.565

Di, H. J., Cameron, K. C., Shen, J. P., Winefield, C. S., O'Callaghan, M., Bowatte, S., et al. (2009). Nitrification driven by bacteria and not archaea in nitrogen-rich grassland soils. Nat. Geosci. 2, 621-624. doi: 10.1038/ngeo613

Edgar, R. C. (2013). UPARSE: highly accurate OTU sequences from microbial amplicon reads. Nat. Methods 10, 996-998. doi: 10.1038/nmeth.2604 
Francis, C. A., Roberts, K. J., Beman, J. M., Santoro, A. E., and Oakley, B. B. (2005). Ubiquity and diversity of ammonia-oxidizing archaea in water columns and sediments of the ocean. Proc. Natl. Acad. Sci. U.S.A. 102, 14683-14688. doi: 10.1073/pnas.0506625102

Freitag, T. E., Chang, L., and Prosser, J. I. (2006). Changes in the community structure and activity of betaproteobacterial ammonia-oxidizing sediment bacteria along a freshwater-marine gradient. Environ. Microbiol. 8, 684-696. doi: 10.1111/j.1462-2920.2005.00947.x

Hayashi, K., Shimomura, Y., Morimoto, S., Uchida, M., Nakatsubo, T., and Hayatsu, M. (2015). Characteristics of ammonia oxidation potentials and ammonia oxidizers in mineral soil under Salix Polaris-moss vegetation in Ny-Ålesund, Svalbard. Polar Biol. 39, 1-17. doi: 10.1007/s00300-015-1829-2

He, J. Z., Shen, J. P., Zhang, L. M., Zhu, Y. G., Zheng, Y. M., Xu, M. G., et al. (2007). Quantitative analyses of the abundance and composition of ammoniaoxidizing bacteria and ammonia-oxidizing archaea of a Chinese upland red soil under long-term fertilization practices. Environ. Microbiol. 9, 2364-2374. doi: 10.1111/j.1462-2920.2007.01358.x

Hooper, A. B., Vannelli, T., Bergmann, D. J., and Arciero, D. M. (1997). Enzymology of the oxidation of ammonia to nitrite by bacteria. Anton. Leeuw. 71, 59-67. doi: 10.1023/A:1000133919203

Hou, J., Cao, X. Y., Song, C. L., and Zhou, Y. Y. (2013a). Predominance of ammonia-oxidizing archaea and nirK-gene-bearing denitrifiers among ammonia-oxidizing and denitrifying populations in sediments of a large urban eutrophic lake (lake Donghu). Can. J. Microbiol. 59, 456-464. doi: 10.1139/cjm2013-0083

Hou, J., Song, C. L., Cao, X. Y., and Zhou, Y. (2013b). Shifts between ammoniaoxidizing bacteria and archaea in relation to nitrification potential across trophic gradients in two large Chinese lakes (Lake Taihu and Lake Chaohu). Water Res. 47, 2285-2296. doi: 10.1016/j.watres.2013.01.042

Jia, Z. J., and Conrad, R. (2009). Bacteria rather than Archaea dominate microbial ammonia oxidation in an agricultural soil. Environ. Microbiol. 11, 2931-2941. doi: 10.1111/j.1462-2920.2009.01891.x

Jiang, H. C., Dong, H. L., Yu, B. S., Lv, G., Deng, S. C., Berzins, N., et al. (2009). Diversity and abundance of ammonia-oxidizing archaea and bacteria in Qinghai Lake, Northwestern China. Geomicrobiol. J. 26, 199-211. doi: 10.1080/ 01490450902744004

Jiang, H. C., Huang, Q. Y., Dong, H. L., Wang, P., Wang, F. P., Li, W. J., et al. (2010). RNA-based investigation of ammonia-oxidizing archaea in hot springs of Yunnan Province, China. Appl. Environ. Microbiol. 76, 4538-4541. doi: 10.1128/AEM.00143-10

Jin, T., Zhang, T., Ye, L., Lee, O. O., Wong, Y. H., and Qian, P. Y. (2011). Diversity and quantity of ammonia-oxidizing archaea and bacteria in sediment of the Pearl River estuary, China. Appl. Microbiol. Biotechnol. 90, 1137-1145. doi: 10.1007/s00253-011-3107-8

Junier, P., Molina, V., Dorador, C., Hadas, O., Kim, O. S., Junier, T., et al. (2010). Phylogenetic and functional marker gene to study ammonia-oxidizing microorganisms (AOM) in the environment. Appl. Microbiol. Biotechnol. 85, 425-440. doi: 10.1007/s00253-009-2228-9

Kayee, P., Sonthiphand, P., Rongsayamanont, C., and Limpiyakorn, T. (2011). Archaeal amoA genes outnumber bacterial amoA genes in municipal wastewater treatment plants in Bangkok. Microb. Ecol. 62, 776-788. doi: 10.1007/s00248-016-0794-9

Könneke, M., Bernhard, A. E., De la Torre, J. R., Walker, C. B., Waterbury, J. B., and Stahl, D. A. (2005). Isolation of an autotrophic ammonia-oxidizing marine archaeon. Nature 437, 543-546. doi: 10.1038/nature03911

Li, M., Cao, H. L., Hong, Y. G., and Gu, J. D. (2010). Spatial distribution and abundances of ammonia-oxidizing archaea (AOA) and ammonia-oxidizing bacteria (AOB) in mangrove sediments. Appl. Microbiol. Biotechnol. 89, 1243-1254. doi: 10.1007/s00253-010-2929-0

Limpiyakorn, T., Fürhacker, M., Haberl, R., Chodanon, T., Srithep, P., and Sonthiphand, P. (2013). amoA-encoding archaea in wastewater treatment plant: a review. Appl. Microbiol. Biotechnol. 97, 1425-1439. doi: 10.1007/s00253-0124650-7

Lipsewers, Y. A., Bale, N. J., Hopmans, E. C., Schouten, S., Damsté, J. S., and Villanueva, L. (2014). Seasonality and depth distribution of the abundance and activity of ammonia oxidizing microorganisms in marine coastal sediments (North Sea). Front. Microbiol. 5:472. doi: 10.3389/fmicb.2014.00472
Liu, Z. H., Huang, S. B., Sun, G. P., Xu, Z., and Xu, M. (2011). Diversity and abundance of ammonia-oxidizing archaea in the Dongjiang River, China. Microbiol. Res. 166, 337-345. doi: 10.1016/j.micres.2010.08.002

Llyd, E. W., and Jody, W. D. (2003). Abundance of bacteria, the CytophagaFlavobacterium cluster and archaea in cold oligotrophic waters and nepheloid layers of the Northwest Passage, Canadian Archipelago. Aquat. Microb. Ecol. 31, 19-31. doi: 10.3354/ame031019

Mao, Y., Yannarell, A. C., Davis, S. C., and Mackie, R. I. (2013). Impact of different bioenergy crops on $\mathrm{N}$-cycling bacterial and archaeal communities in soil. Environ. Microbiol. 15, 928-942. doi: 10.1111/j.1462-2920.2012.02844.x

Mosier, A. C., and Francis, C. A. (2008). Relative abundance and diversity of ammonia-oxidizing archaea and bacteria in the San Francisco Bay estuary. Environ. Microbiol. 10, 3002-3016. doi: 10.1111/j.1462-2920.2008. 01764.x

Niu, J., Kasuga, I., Kurisu, F., Furumai, H., and Shigeeda, T. (2013). Evaluation of autotrophic growth of ammonia-oxidizers associated with granular activated carbon used for drinking water purification by DNA-stable isotope probing. Water Res. 47, 7053-7065. doi: 10.1016/j.watres.2013.07.056

Olsson, P. A., Hansson, M. C., and Burleigh, S. H. (2006). Effect of P availability on temporal dynamics of carbon allocation and glomus intraradices high-affinity $\mathrm{P}$ transporter gene induction in Arbuscular Mycorrhiza. Appl. Environ. Microbiol. 72, 4115-4120. doi: 10.1128/AEM.02154-05

Park, H. D., Wells, G. F., Bae, H., Criddle, C. S., and Francis, C. A. (2006). Occurrence of ammonia-oxidizing archaea in wastewater treatment plant bioreactors. Appl. Environ. Microbiol. 72, 5643-5647. doi: 10.1128/AEM. 00402-06

Park, J. J., Byun, I. G., Yu, J. C., Park, S. R., Ju, D. J., Hur, S. H., et al. (2008). Analysis of nitrifying bacterial communities in aerobic biofilm reactors with different conditions using molecular techniques. Water Sci. Technol. 57, 1889-1899. doi: 10.2166/wst.2008.622

Pester, M., Rattei, T., Flechl, S., Gröngróft, A., Richter, A., Overmann, J., et al. (2012). amoA-based consensus phylogeny of ammonia-oxidizing archaea and deep sequencing of $a m o A$ genes from soils of four different geographic regions. Environ. Microbiol. 14, 525-539. doi: 10.1111/j.1462-2920.2011.02666.x

Qiu, Z., Luo, Z. X., Zhao, Y. L., and Yan, C. Z. (2013). Effect of dissolved oxygen on the diversity of ammonia-oxidizing microorganisms in enrichment culture from estuarine wetland surface sediments and ammonia-oxidizing rate. Environ. Sci. 34, 532-539.

Ran, X. B., Zang, J. Y., Wei, Q. S., Guo, J. S., Yin, X. F., Liu, W., et al. (2012). Hyposia and its cause of formation in the adjacent waters of Rushan Bay. Adv. Mar. Sci. 30, 347-356. doi: 10.3969/j.issn.1671-6647.2012.03.005

Rotthauwe, J. H., Witzel, K. P., and Liesack, W. (1997). The ammonia monooxygenase structural gene $a m o A$ as a functional marker: molecular fine-scale analysis of natural ammonia-oxidizing populations. Appl. Environ. Microbiol. 63, 4704-4712.

Sahan, E., and Muyzer, G. (2008). Diversity and spatio-temporal distribution of ammonia-oxidizing archaea and bacteria in sediments of the Westerschelde estuary. FEMS Microbiol. Ecol. 64, 175-186. doi: 10.1111/j.1574-6941.2008. 00462.x

Santoro, A. E., Francis, C. A., De Sieyes, N. R., and Boehm, A. B. (2008). Shifts in the relative abundance of ammonia-oxidizing bacteria and archaea across physiochemical gradients in a subterranean estuary. Environ. Microbiol. 10, 1068-1079. doi: 10.1111/j.1462-2920.2007.01547.x

Schleper, C., Jurgens, G., and Jonuscheit, M. (2005). Genomic studies of uncultivated archaea. Nat. Rev. 3, 479-488. doi: 10.1038/nrmicro1159

Shen, J. P., Zhang, L. M., Zhu, Y. G., Zhang, J. B., and He, J. Z. (2008). Abundance and composition of ammonia-oxidizing bacteria and ammoniaoxidizing archaea communities of an alkaline sandy loam. Environ. Microbiol. 10, 1601-1611. doi: 10.1111/j.1462-2920.2008.01578.x

Sims, A., Gajaraj, S., and Hu, Z. Q. (2012a). Seasonal population changes of ammonia-oxidizing organisms and their relationship to water quality in a constructed wetland. Ecol. Eng. 40, 100-107. doi: 10.1016/j.ecoleng.2011. 12.021

Sims, A., Horton, J., Gajaraj, S., Mclntosh, S., Miles, R. J., Mueller, R., et al. (2012b). Temporal and spatial distributions of ammonia-oxidizing archaea and bacteria and their ratios as an indicator of oligotrophic conditions in natural wetlands. Water Res. 46, 4121-4129. doi: 10.1016/j.watres.2012.05.007 
Tago, K., Okubo, T., Shimomura, Y., Kikuchi, Y., Hori, T., Nagayama, A., et al. (2015). Environmental factors shaping the community structure of ammoniaoxidizing bacteria and archaea in Sugarcane field soil. Microbes. Environ. 30, 21-28. doi: 10.1264/jsme2.ME14137

Tamura, K., Stecher, G., Peterson, D., Filipski, A., and Kumar, S. (2013). MEGA6: molecular evolutionary genetics analysis version 6.0. Mol. Biol. Evol. 30, 2725-2729. doi: 10.1093/molbev/mst197

ter Braak, C., and Šmilauer, P. (2002). CANOCO Reference Manual and Canodraw for Window User's Guide: Software for Canonical Community Ordination (Version 4.5). Ithaca, NY: Microcomputer Power.

Tourna, M., Freitag, T. E., Nicol, G. W., and Prosser, J. I. (2008). Growth, activity and temperature responses of ammonia-oxidizing archaea and bacteria in soil microcosms. Environ. Microbiol. 10, 1357-1364. doi: 10.1111/j.1462-2920.2007. 01563.x

Treusch, A. H., Leininger, S., Kletzin, A., Schuster, S. C., Klenk, H. P., and Schleper, C. (2005). Novel genes for nitrite reductase and amoA-related proteins indicate a role of uncultivated mesophilic Crenarchaeota in nitrogen cycling. Environ. Microbiol. 7, 1985-1995. doi: 10.1111/j.1462-2920.2005.00906.x

Venter, J. C., Remington, K., Heidelberg, J. F., Halpern, A. L., Rusch, D., Eisen, J. A., et al. (2004). Environmental genome shotgun sequencing of the Sargasso Sea. Science 304, 66-74. doi: 10.1126/science.1093857

Vissers, E. W., Blaga, C. I., Bodelier, P. L., Muyzer, G., Schleper, C., Sinninghe, D. J. S., et al. (2013). Seasonal and vertical distribution of putative ammoniaoxidizing thaumarchaeotal communities in an oligotrophic lake. FEMS Microbiol. Ecol. 83, 515-526. doi: 10.1111/1574-6941.12013

Wang, B. Z., Zhao, J., Guo, Z. Y., Ma, J., Xu, H., and Jia, Z. J. (2015). Differential contributions of ammonia oxidizers and nitrite oxidizers to nitrification in four paddy soils. ISME J. 9, 1062-1075. doi: 10.1038/ismej.2014.194

Wang, J., Wang, W. D., and Gu, J. D. (2014). Community structure and abundance of ammonia-oxidizing archaea and bacteria after conversion from soybean to rice paddy in albic soils of Northeast China. Appl. Microbiol. Biotechnol. 98, 2765-2778. doi: 10.1007/s00253-013-5213-2

Wankel, S. D., Mosier, A. C., Hansel, C. M., Paytan, A., and Francis, C. A. (2011). Spatial variability in nitrification rates and ammonia-oxidizing microbial communities in the agriculturally impacted Elkhorn Slough estuary, California. Appl. Environ. Microbiol. 77, 269-280. doi: 10.1128/AEM.01318-10

Winogradsky, S. (1890). Researchers sur les organisms de la nitrification. Ann. Instit. Pasteur. 4, 213-331.

Xia, F., Zeleke, J., Sheng, Q., Wu, J. H., and Quan, Z. X. (2015). Communities of ammonia oxidizers at different stages of Spartina alterniflora invasion in salt marshes of Yangtze River estuary. J. Microbiol. 53, 311-320. doi: 10.1007/ s12275-015-4660-0

Yao, H. Y., Gao, Y. M., Nicol, G. W., Campbell, C. D., Prosser, J. I., Zhang, L. M., et al. (2011). Links between ammonia oxidizer community structure, abundance, and nitrification potential in acidic soils. Appl. Environ. Microbiol. 77, 4618-4625. doi: 10.1128/AEM.00136-11

Ye, L., Zhu, G. B., Wang, Y., Feng, X. J., Wang, W. D., Wang, S. Y., et al. (2011). Abundance and biodiversity of ammonia-oxidizing archaea and bacteria in littoral wetland of Baiyangdian Lake, North China. Acta Ecol. Sin. 31, 2209-2215.

Yu, S. L., Qiao, Y. L., Han, Y. Q., and Zhang, X. H. (2015). Differences between ammonia-oxidizing microorganisms in phylogeny and physiological ecology. Microbiol. China 42, 2457-2465. doi: 10.13344/j.microbiol.china. 150115

Yu, S. L., Yao, P., Liu, J. W., Zhao, B., Zhang, G., Zhao, M., et al. (2016). Diversity, abundance, and niche differentiation of ammonia-oxidizing prokaryotes in mud deposits of the Eastern China Marginal Seas. Front. Microbiol. 7:137. doi: $10.3389 /$ fmicb. 2016.00137

Zhang, Y., Chen, L. J., Sun, R. H., Dai, T. J., Tian, J. P., and Wen, D. H. (2015). Ammonia-oxidizing bacteria and archaea in wastewater treatment plant sludge and nearby coastal sediment in an industrial area in China. Appl. Microbiol. Biotechnol. 99, 4495-4507. doi: 10.1007/s00253-014-6352-9

Zhang, Y., Chen, L. J., Sun, R. H., Dai, T. J., Tian, J. P., Zheng, W., et al. (2016). Population and diversity of ammonia-oxidizing archaea and bacteria in a pollutants' receiving area in Hangzhou Bay. Appl. Microbiol. Biotechnol. 100, 6035-6045. doi: 10.1007/s00253-016-7421-Z

Zhao, D. Y., Luo, J., Wang, J. Q., Huang, R., Guo, K., Li, Y., et al. (2015). The influence of land use on the abundance and diversity of ammonia oxidizers. Curr. Microbiol. 70, 282-289. doi: 10.1007/s00284-014-0714-5

Zheng, Y. L., Hou, L. J., Liu, M., Lu, M., Zhao, H., Yin, G., et al. (2013). Diversity, abundance, and activity of ammonia-oxidizing bacteria and archaea in Chongming eastern intertidal sediments. Appl. Microbiol. Biotechnol. 97, 8351-8363. doi: 10.1007/s00253-012-4512-3

Zheng, Y. L., Hou, L. J., Newell, S., Liu, M., Lu, M., Zhao, H., et al. (2014). Community dynamics and activity of ammonia-oxidizing prokaryotes in intertidal sediments of the Yangtze estuary. Appl. Environ. Microbiol. 80, 408-419. doi: 10.1128/AEM.03035-13

Conflict of Interest Statement: The authors declare that the research was conducted in the absence of any commercial or financial relationships that could be construed as a potential conflict of interest.

Copyright (C) $2018 \mathrm{He}$, Zhen, Mi, Fu and Yu. This is an open-access article distributed under the terms of the Creative Commons Attribution License (CC BY). The use, distribution or reproduction in other forums is permitted, provided the original author(s) and the copyright owner are credited and that the original publication in this journal is cited, in accordance with accepted academic practice. No use, distribution or reproduction is permitted which does not comply with these terms. 